\title{
Separation and Preconcentration of Trace Uranium(VI) by Solid Phase Extraction with 2,3-Dihydroxynaphthalene and Cetyltrimethylammonium Bromide on Molten Naphthalene and Its LED Fluorimetric Determination in Water Samples
}

\author{
Susanta Kumar Pradhan ${ }^{* \dagger}$ and Balram AMBade** \\ *Chemical Laboratory, Atomic Minerals Directorate for Exploration and Research, Department of Atomic Energy, \\ Eastern Region, Khasmahal, Jamshedpur-831002, India \\ **Department of Chemistry, National Institute of Technology, Jamshedpur-831014, India
}

\begin{abstract}
A simple and rapid solid phase extraction (SPE) procedure has been developed for the extraction and determination of uranium in water samples. The method is based upon the adsorption of uranium(VI)-2,3-dihydroxynaphthalene complex on microcrystalline naphthalene at the $\mathrm{pH}$ range $10-12$ in the presence of a counter cation cetyltrimethylammonium ion. The solid mass consisting of uranium-2,3-dihydroxynaphthalene-CTA complex and naphthalene is ignited in the furnace at a temperature of $700^{\circ} \mathrm{C}$ for $1 \mathrm{~h}$ and then digested in dil. $\mathrm{HNO}_{3}$ solution. Uranium is then determined by LED fluorimetry using fluorescence enhancing pyrophosphate buffer. The effects of different variables like $\mathrm{pH}$ of the solution, reagent concentrations, counter cations, stirring time, interfering ions etc. have been investigated thoroughly for the quantitative recovery of uranium. The accuracy of the developed method has been ascertained by standard addition method as well as conventional pellet fluorimetry method involving co-precipitation of uranium using aluminum phosphate as a carrier.
\end{abstract}

Keywords Uranium, solid phase extraction, 2,3-dihydroxynaphthalene, microcrystalline naphthalene, LED fluorimetry

(Received June 7, 2019; Accepted September 2, 2019; Advance Publication Released Online by J-STAGE September 13, 2019)

\section{Introduction}

Uranium is an important element in the nuclear industry especially as an energy source. $\mathrm{U}^{235}$, an isotope of uranium, is the only naturally occurring fissile element available in the earth's crust that can be directly used in a nuclear reactor to produce energy through nuclear fission. Low concentrations of uranium are normally present in various complex materials, like nuclear energy sights, alloys, plants, water, effluents, etc. Hydro-geochemical exploration is one of the methods of exploration to locate concealed uranium deposits. The application of water sampling in the geochemical exploration of uranium is based on its property of high solubility on the uranium(VI) oxidation state. U(VI) forms complexes with chloride, carbonate, sulfate, phosphate, fluorides, etc. present in natural water. As ground water flows, it tends to converge in lakes and streams. Therefore, systematic water sampling allows the detection of hydro-geochemical dispersion haloes of hidden uranium deposits. ${ }^{1}$ Hence, it is very important from an analytical point of view to develop a sensitive, selective, rapid method for its quantitative determination present in trace and ultra-trace levels.

There are various methods available for the determination of uranium in geological samples. Mention may be made of a few such as gravimetry, volumetry, UV-visible spectrophotometry,

† To whom correspondence should be addressed.

E-mail: skpradhan.amd@gov.in fluorimetry (pellet and LED/laser), X-ray fluorescence spectrometry (XRF), gamma-ray spectrometry, neutron activation analysis (NAA) as well as fission track method, etc. ${ }^{2}$ Spectrophotometric determination of uranium using various complexing agents after extraction of its complexes in some organic solvents lacks sensitivity and selectivity. ${ }^{3-5}$ Although atomic absorption spectroscopy, ${ }^{6}$ neutron activation analysis, ${ }^{7}$ $\mathrm{X}$-ray fluorescence, ${ }^{8}$ ICP-OES and ICP-MS ${ }^{9,10}$ may be applied for the determination of uranium in complex samples like rocks, minerals, concentrates etc., these instruments are expensive, need day-to-day high maintenance costs and they are not free from various types of inherent interference. ${ }^{6-10}$ Determination of uranium in these samples by fluorimetry is a valuable tool in the uranium exploration. The most sensitive method for the determination of trace levels (ppm to $\mathrm{ppb}$ ) of uranium is based upon the measurement of its fluorescence; either in sodium fluoride melts in the case of pellet fluorimetry, or in phosphate medium in the case of laser/LED fluorimetry. However, for the determination of uranium in water samples, where uranium is present in ppb to ppt levels, the energy of the excitation source (fluorescent lamp) in pellet fluorimetry is too weak to excite fluorescence. Therefore, instruments with high energy excitation sources like laser or LED are used for the determination of uranium at this ultra-trace level. This is because fluorescence intensity $(F)$ is directly proportional to the intensity $(I)$ of the excitation source $(F \propto I)$, which leads the favorable detection limit of these instruments. However, an LED based fluorimeter is preferable due to higher stability of the excitation source, 
wide linear working range up to $1000 \mathrm{ppb}$ and longer life of LED. ${ }^{11}$

However, direct determination of uranium in water samples is impossible when the concentration of the uranium is below the determination limit of the instrument used. Therefore, preconcentration methods are very much essential to bring the concentration of uranium to the desired level of an instrument like laser/LED fluorimetry. The widely used techniques for the separation and preconcentration of metal ion include solvent extraction, co-precipitation, ion-exchange, solid phase extraction, cloud point extraction, etc. All the techniques in their own have some advantages and disadvantages. However, recent publication on continuous liquid-liquid extraction of uranium from uranium containing wastewater using an organic phase refining type emulsion flow extractor has gained significant attention. ${ }^{12}$ Almost all fluorimetry methods require separation of uranium from other elements that may interfere with the determination of uranium. Although liquid-liquid solvent extraction involving well known organic solvents like TBP, TOPO, $\mathrm{D}_{2}$ EHPA and ethyl acetate are used for extraction of uranium, they are not free from disadvantages, including consumption of time, high labor cost and need for a large volume of high purity solvent, etc. On the other hand, solid phase extraction (solid-liquid extraction) offers several advantages over liquid-liquid extraction, such as high enrichment factor, absence of emulsion, minimal costs due to low consumption of reagent, flexibility and safety with respect to hazardous samples.

A number of solid phase extractants (SPE) like chelating resin, cellulose, silica gel, metal hydroxides, activated carbon, etc. have been investigated for the separation and preconcentration of inorganic metal ions. Appropriate organic ligands can be chemically or physically supported on various substrates, thus providing complexing or chelating sorbents for the separation and preconcentration of metal ions. ${ }^{13}$ Naphthalene is known as an excellent extractant at high temperatures but cannot be applied to thermally unstable complexes. Several workers have used solid phase extraction based on adsorption of metal chelates on microcrystalline naphthalene, which is more rapid and convenient and has been applied to many types of metal complexes. Sanjay Kumar et al. ${ }^{14}$ used solid phase extractant (a homogeneous mixture of TOPO and naphthalene) for separation of uranium in geological samples and achieved determination by laser induced fluorimetry method. Naveen Kumar et al. ${ }^{15}$ used oxine supported on microcrystalline naphthalene for preconcentration of uranium and other metal ions and achieved determination by ICP-OES. Several other works ${ }^{16-21}$ have also used chelating agent supported on microcrystalline naphthalene for the separation of uranium from different matrices.

The reagent 2,3-dihydroxynaphthalene $\left(2,3-\mathrm{H}_{2} \mathrm{ND}\right)$ is a wellknown $\mathrm{O}-\mathrm{O}^{\prime}$ type bi-dentate ligand. It has been used as an extractant in liquid-liquid solvent extraction for several elements like uranium, ${ }^{22}$ thorium, ${ }^{23}$ rare earth elements, ${ }^{24}$ molybdenum,,${ }^{25}$ manganese, ${ }^{26}$ and iron, etc. Tarafder et al. ${ }^{22}$ used this reagent for liquid-liquid solvent extraction of uranium in silicate rock samples. However, an extant literature survey shows that no such report is available for solid phase extraction of uranium on microcrystalline naphthalene with this cited reagent. This prompted the authors to undertake a detailed study to establish a method to separate and preconcentrate uranium in water samples by solid phase extraction using the extractant, 2,3-dihydroxynaphthalene $\left(2,3-\mathrm{H}_{2} \mathrm{ND}\right)$ in the presence of a counter cation such as cetyltrimethylammonium bromide (CTAB) on microcrystalline naphthalene. Based upon this separation and preconcentration technique, a highly effective and alternative method for the LED fluorimetric determination of ultra-trace level (sub-ppb) uranium in water samples has been developed.

In the present paper, details of a systematic study have been encompassed on the development of a solid phase extractive LED fluorimetric method for the determination of uranium in water samples.

\section{Experimental}

\section{Apparatus}

One pulsed LED (light emitting diode) fluorimeter (Model: UA-2, make: Quantalase India Pvt. Ltd., Indore, India) was used for fluorescence measurement of uranium in aqueous medium at the $\lambda_{\text {excitation }}$ and $\lambda_{\text {emmision }}$ of 405 and $516 \mathrm{~nm}$, respectively. Similarly, one pellet fluorimeter (Model: FL 6224A, make: Electronics Corporation of India Ltd., Hyderabad, India) was used for fluorescence measurement of uranium in solid (pellet) medium at the $\lambda_{\text {excitation }}$ and $\lambda_{\text {emmision }}$ of 365 and $565 \mathrm{~nm}$, respectively. One $\mathrm{pH}$ meter (Model: L1-120, make: ELICO, Hyderabad, India) was used for $\mathrm{pH}$ measurement. A muffle furnace was used for the fusion of the flux at $850^{\circ} \mathrm{C}$.

\section{Standards and reagents}

$\mathrm{U}_{3} \mathrm{O}_{8}$ standard $\left(1 \mathrm{mg} \mathrm{mL}^{-1}\right)$ : Weighed $0.25 \mathrm{~g} \mathrm{U}_{3} \mathrm{O}_{8}$ (dried at $105^{\circ} \mathrm{C}$ ) in $250 \mathrm{~mL}$ volumetric flask, dissolved in $7.5 \mathrm{~mL}$ conc. $\mathrm{HNO}_{3}$, diluted with water and made up to the mark with distilled water to obtain $1 \mathrm{mg} \mathrm{mL}^{-1} \mathrm{U}_{3} \mathrm{O}_{8}$ solution. Then the $1 \mu \mathrm{g} \mathrm{mL}^{-1}$ $\mathrm{U}_{3} \mathrm{O}_{8}$ solution was prepared by diluting the stock solution. This was further diluted to prepared ppb level $\mathrm{U}_{3} \mathrm{O}_{8}$ working standard solution.

Preparation of 2,3-dihydroxynaphthalene $1 \%(\mathrm{w} / \mathrm{v})$ was done by dissolving $1 \mathrm{~g}$ in $100 \mathrm{~mL}$ ethyl acetate. Sodium acetate $10 \%$ $(\mathrm{w} / \mathrm{v})$, potassium hydroxide $5 \%(\mathrm{w} / \mathrm{v})$, cetyltrimethylammonium bromide (CTAB) $1 \%(\mathrm{w} / \mathrm{v})$ and $\mathrm{Na}_{2}$ EDTA $10 \%$ (w/v) were prepared in aqueous solutions separately. Naphthalene (scintillation grade) solid, tetra sodium pyrophosphate buffer $5 \%(\mathrm{w} / \mathrm{v}$ ) solution (adjusted $\mathrm{pH} \sim 7$ using a few drops of 1:1 ortho-phosphoric acid) was used for fluorescence enhancing reagent for uranium. Unless otherwise stated, all reagents and chemicals used were of AR/GR grade of standard make.

\section{General Procedure}

\section{Pretreatment of samples}

Water (ground water) samples were collected from different field areas of eastern India in pre-washed polyethylene bottles. All the water samples were filtered through a $0.45-\mu \mathrm{m}$ pore size membrane filter to remove suspended particulate matter and acidified with $1 \%$ nitric acid.

\section{Solid phase extraction and determination of uranium}

To a $250-\mathrm{mL}$ water sample taken in a $500-\mathrm{mL}$ beaker containing up to $10 \mu \mathrm{g}$ uranium was added with $5 \mathrm{~mL}$ of $1 \%$ 2,3-dihydroxynaphthalene $\left(2,3-\mathrm{H}_{2} \mathrm{ND}\right)$ in ethyl acetate. This was stirred well with a magnetic stirrer. Then, $5 \mathrm{~mL}$ of $1 \%$ cetyltrimethylammonium bromide (CTAB) was added followed by the addition of $2.0 \mathrm{~g}$ naphthalene, which was melted at $80-90^{\circ} \mathrm{C}$ and stirred continuously for about $10 \mathrm{~min}$ in the heated condition. To this was then added with $10 \mathrm{~mL}$ of $10 \%$ $\mathrm{CH}_{3} \mathrm{COONa}, 3 \mathrm{~mL}$ of $10 \% \mathrm{Na}_{2}$ EDTA solution and $5 \mathrm{~mL}$ of $5 \%$ $\mathrm{KOH}$, and the $\mathrm{pH}$ was adjusted in the range of $10-12$ and stirred continuously for another $20 \mathrm{~min}$ in the heated condition (at molten naphthalene temperature, $\sim 80^{\circ} \mathrm{C}$ ). After cooling, the solid mass containing the uranium ion associated complex 


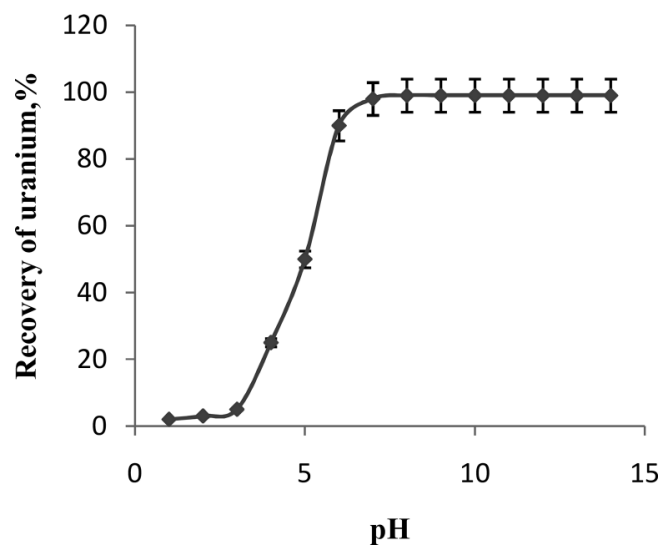

Fig. 1 Plot of $\%$ recovery of $10 \mu \mathrm{g}$ uranium $v s . \mathrm{pH}$ of the solution at the time of solid phase extraction (amount of 2,3- $\mathrm{H}_{2} \mathrm{ND} / 0.31 \times$ $10^{-3} \mathrm{~mol}$, amount of $\mathrm{CTAB} / 0.14 \times 10^{-3} \mathrm{~mol}$, amount of naphthalene/ $15.6 \times 10^{-3} \mathrm{~mol}$, stirring time: $30 \mathrm{~min}$ ).

adsorbed on microcrystalline naphthalene was filtered through Whatman filter paper 41 . The filter paper containing a solid mass in a platinum crucible was charred in a muffle furnace at $700^{\circ} \mathrm{C}$ for about $1 \mathrm{~h}$ in order to destroy the organic matter completely; otherwise the organic matter quenches the uranium fluorescence in aqueous solution. The solid mass was treated with a few $\mathrm{ml}$ of diluted $\mathrm{HNO}_{3}$ and dried. This was digested with $2 \mathrm{~mL}$ pyrophosphate buffer (5\%), which was also used as a fluorescence enhancing reagent and taken in a $10-\mathrm{mL}$ volumetric flask and made up to the volume with distilled water. The fluorescence intensity was then measured in an LED based fluorimeter. The process blank was also run in a similar way. A wide calibration curve (not shown here) comprising fluorescent counts against known concentrations of standards up to $1000 \mathrm{ppb}$ was prepared and calculated the concentration of uranium for an unknown sample solution from the calibration curve.

\section{Results and Discussion}

During the last few decades, separation and preconcentration based on solid-liquid extraction with microcrystalline naphthalene modified with different chelates has received great attraction. As has already been discussed in the prelude of the paper, several workers have used solid phase extraction of uranium on microcrystalline naphthalene modified with different chelates. ${ }^{14-21}$ However, solid phase extraction of uranium on microcrystalline naphthalene with the bi-dentate chelate 2,3-dihydroxynaphthalene in the presence of cetyltrimethylammonium bromide has not so far been reported in the existing chemical literature. This prompted authors to explore the present study for separation and preconcentration of uranium in water samples followed by its LED fluorimetric determination.

In what follows are given details of studies on the variables affecting the solid-liquid extraction of uranium from a sample solution.

\section{Effect of $p H$ on the extraction of uranium}

In order to show the effect of $\mathrm{pH}$ on the extraction of uranium as uranium-2,3-dihydroxynaphthalene $\left(2,3 \mathrm{H}_{2} \mathrm{ND}\right)$ complex on microcrystalline naphthalene, a set of solutions containing $10 \mu \mathrm{g}$ uranium each was studied over a $\mathrm{pH}$ range of 1 to 12 . Under optimized conditions, it was found that the extraction of uranium was observed from $\mathrm{pH} 5$ to 12 , but the maximum

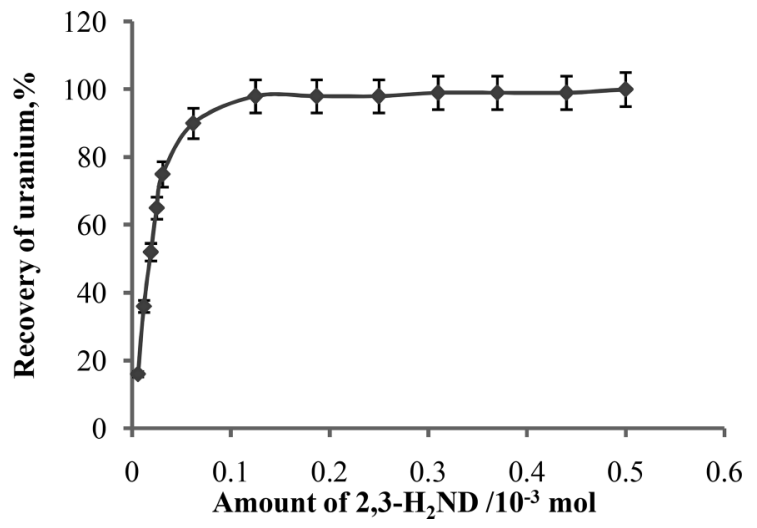

Fig. 2 Plot of $\%$ recovery of $10 \mu \mathrm{g}$ uranium vs. amount of 2,3$\mathrm{H}_{2} \mathrm{ND} / 10^{-3} \mathrm{~mol}$ (amount of CTAB $/ 0.14 \times 10^{-3} \mathrm{~mol}$, amount of naphthalene/15.6 $\times 10^{-3} \mathrm{~mol}, \mathrm{pH}$ : $10-12$, stirring time: $30 \mathrm{~min}$ ).

efficiency and reproducibility of the extraction was achieved in the range of $\mathrm{pH} 10-12$, which is shown in Fig. 1. This indicates that the uranium-2,3-dihydroxynaphthalene (2,3$\mathrm{H}_{2} \mathrm{ND}$ ) complex was adsorbed on microcrystalline naphthalene quantitatively and the recovery of uranium was more than $95 \%$.

Effect of concentration of 2,3-dihydroxynaphthalene $\left(2,3-\mathrm{H}_{2} \mathrm{ND}\right)$

In order to investigate the effect of the amount of $2,3-\mathrm{H}_{2} \mathrm{ND}$ on the quantitative extraction of uranium, the extraction studies were conducted by varying the amounts of $2,3-\mathrm{H}_{2} \mathrm{ND}$ from 0.1 to $10 \mathrm{~mL}$ of $\left.1 \%(\mathrm{w} / \mathrm{v}) 2,3-\mathrm{H}_{2} \mathrm{ND}\right)$ for $10 \mu \mathrm{g}$ uranium, keeping the other parameters constant. The results showed that the percentage recovery of uranium in terms of fluorescence intensity increases gradually with the increasing concentration of chelates. At the reagent concentration of $0.125 \times 10^{-3} \mathrm{~mol}$, the uranium-2,3- $\mathrm{H}_{2} \mathrm{ND}$ complexes were adsorbed on microcrystalline naphthalene quantitatively. However, in order to allow for reagent impurity and the scope for the complexation of higher amounts of uranium, a concentration of $0.31 \times 10^{-3} \mathrm{~mol}$ $\left(5 \mathrm{~mL}\right.$ of $1 \% 2,3-\mathrm{H}_{2} \mathrm{ND}$ ) is recommended. This is illustrates in Fig. 2. Uranium forms its anionic complex with 2,3-dihydroxynaphthalene at the alkaline $\mathrm{pH} .{ }^{22}$

\section{Effect of cetyltrimethylammonium bromide (CTAB)}

The effect of CTAB on the complexation of uranium with $2,3-\mathrm{H}_{2} \mathrm{ND}$ and its subsequent solid phase extraction on microcrystalline naphthalene was studied by varying its concentration from dilute to concentrate solution. It was found that $10 \mathrm{~mL}$ of $0.01 \mathrm{M}\left(0.1 \times 10^{-3} \mathrm{~mol}\right)$ solution was required for the complete extraction of $10 \mu \mathrm{g}$ uranium. However, in the presence of higher amounts of uranium and for reagent impurities, $5 \mathrm{~mL}$ of $1 \% \mathrm{CTAB}\left(0.14 \times 10^{-3} \mathrm{~mol}\right)$ is recommended. It was observed that a $100 \%$ retention of the uranyl-2,3- $\mathrm{H}_{2} \mathrm{ND}$ complex took place only in the presence of CTAB. In the absence of CTAB, only $\sim 60 \%$ retention of the uranyl-2,3- $\mathrm{H}_{2} \mathrm{ND}$ complex took place on microcrystalline naphthalene. This indicates that a part of the uranyl complex with $2,3-\mathrm{H}_{2} \mathrm{ND}$ is negatively charged and in the presence of positively charged $\mathrm{CTA}^{+}$, neutral ion-associated complex is formed. Earlier, Tarafder et al..$^{22}$ reported that 3 moles of 2,3- $\mathrm{H}_{2} \mathrm{ND}$ and 2 moles of CTAB took part in the formation of an uranyl ion associated complex. In the case of 2,3- $\mathrm{H}_{2} \mathrm{ND}, 2$ moles are present within the co-ordination sphere and $1 \mathrm{~mol}$ is present as an adductant. The tentative composition of the ion-associated complex is formulated as $(\mathrm{CTA})_{2}\left[\mathrm{UO}_{2}(\mathrm{ND})_{2}\right] \cdot \mathrm{H}_{2} \mathrm{ND}$. The stoichiometry 


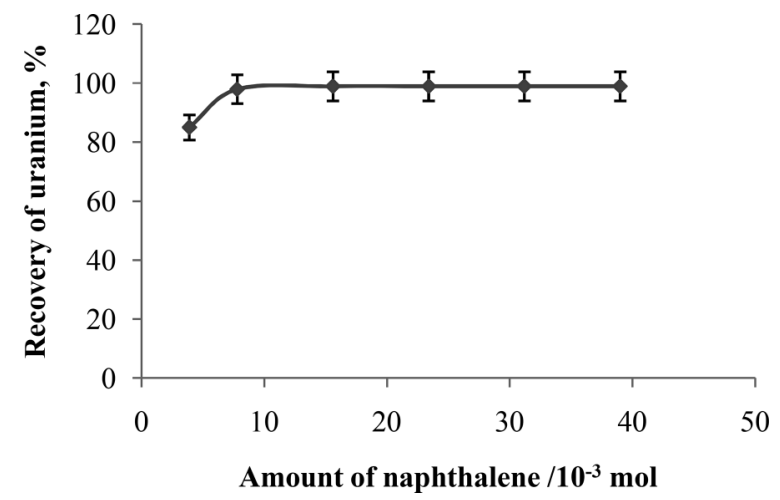

Fig. 3 Plot of $\%$ recovery of $10 \mu \mathrm{g}$ uranium vs. amount of naphthalene $/ 10^{-3} \mathrm{~mol}$ (amount of 2,3- $\mathrm{H}_{2} \mathrm{ND} / 0.31 \times 10^{-3} \mathrm{~mol}$, amount of $\mathrm{CTAB} / 0.14 \times 10^{-3} \mathrm{~mol}, \mathrm{pH}: 10-12$, stirring time: $30 \mathrm{~min}$ ).

between $\mathrm{UO}_{2}{ }^{2+}, 2,3-\mathrm{H}_{2} \mathrm{ND}$ and CTAB is $1: 3: 2$.

It is pertinent to mention here that the extracted species $(\mathrm{CTA})_{2}\left[\mathrm{UO}_{2}(\mathrm{ND})_{2}\right] \cdot \mathrm{H}_{2} \mathrm{ND}$ on microcrystalline naphthalene is destroyed by ignition or perchloric acid treatment in order to remove the organic matter, which otherwise quenches uranium fluorescence. The fluorescence of free uranyl ions are enhanced by the addition of fluorescence enhancing reagent (FER). The excitation and emission spectra of uranyl ions in phosphate medium had already been reported in earlier literature..$^{27-29}$

\section{Effect of the amounts of naphthalene}

In order to adsorb uranyl-2,3-dihydroxynaphthalene complexes quantitatively, the amount of naphthalene was also chosen carefully. In order to investigate the effect of the amount of naphthalene on the quantitative recovery of $10 \mu \mathrm{g}$ uranium, the recovery studies were conducted by varying the amounts of naphthalene from 0.5 to $5 \mathrm{~g}\left(3.9-39 \times 10^{-3} \mathrm{~mol}\right)$. It was found that uranium could be recovered quantitatively (95\%) with $1 \mathrm{~g}$ naphthalene. However, in order to allow for reagent impurity and the scope for the adsorption of higher amounts of uranium, $2 \mathrm{~g}\left(15.6 \times 10^{-3} \mathrm{~mol}\right)$ naphthalene is recommended. This is shown in Fig. 3.

\section{Effect of stirring time}

In order to investigate the effect of stirring time on the extraction efficiency, the experiments were carried out from 5 to $60 \mathrm{~min}$. A total of $30 \mathrm{~min}$ stirring time was sufficient for the quantitative extraction of $10 \mu \mathrm{g}$ uranium. Hence, a 30-min stirring time is recommended. Figure 4 illustrates this.

\section{Effect on the sequence of the addition of reagents}

It is important to mention here that the anionic complex of uranium with 2,3- $\mathrm{H}_{2} \mathrm{ND}$ is kinetically so stable that once formed at lower $\mathrm{pH}$, i.e., slightly acidic to neutral condition, it is not broken even in alkaline condition. Hence, it is always recommended that the reagent $2,3-\mathrm{H}_{2} \mathrm{ND}$ is first added to the uranium solution and then the $\mathrm{pH}$ of the medium is raised to $10-12$, where the solid phase extraction of uranium is carried out quantitatively.

\section{Effect of electrolytes}

The role of sodium acetate has no effect on quantitative extraction of uranium on microcrystalline naphthalene except its buffering capacity at the $\mathrm{pH}$ of $4-6$. As has already been mention in the previous paragraph that uranium forms a kinetically stable anionic complex with $2,3-\mathrm{H}_{2} \mathrm{ND}$ in slightly

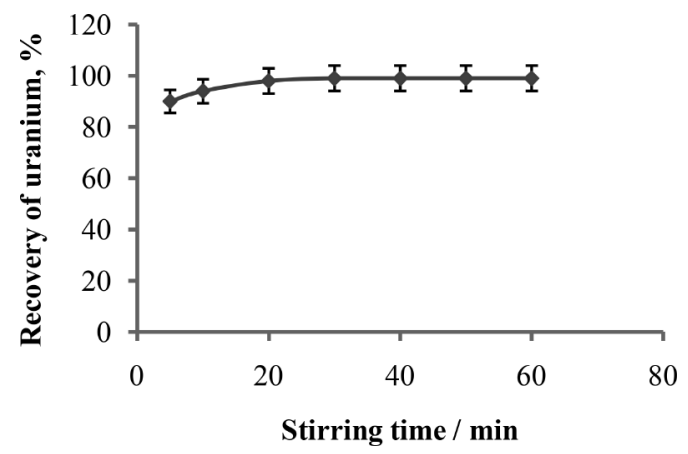

Fig. 4 Plot of $\%$ recovery of $10 \mu \mathrm{g}$ uranium $v s$. stirring time $/ \mathrm{min}$ (amount of $2,3-\mathrm{H}_{2} \mathrm{ND} / 0.31 \times 10^{-3} \mathrm{~mol}$, amount of CTAB/0.14 $\times 10^{-3}$ mol, amount of naphthalene/15.6 $\times 10^{-3} \mathrm{~mol}, \mathrm{pH}$ : $10-12$ ).

acidic to neutral medium i.e., in the $\mathrm{pH}$ range $4-6 \cdot \mathrm{Na}_{2} \mathrm{EDTA}$ is used to mask the quenchers, like $\mathrm{Ca}, \mathrm{Fe}, \mathrm{Mn}, \mathrm{Cu}, \mathrm{Co}, \mathrm{Cr}, \mathrm{Ni}$, etc. Similarly, the role of $\mathrm{KOH}$ is to increase the $\mathrm{pH}$ of the solution to $10-12$, where to maximize the extraction efficiency.

\section{Effect of diverse ions}

In order to investigate the effects of common co-existing ions $\left(\mathrm{Na}^{+}, \mathrm{K}^{+}, \mathrm{Ca}^{2+}, \mathrm{Mg}^{2+}, \mathrm{Fe}^{3+}, \mathrm{Al}^{3+}, \mathrm{Ti}^{4+}, \mathrm{Mn}^{2+}, \mathrm{Cu}^{2+}, \mathrm{Co}^{2+}, \mathrm{Ni}^{2+}\right.$, $\mathrm{Pb}^{2+}, \mathrm{Cr}^{3+}$, etc.) in water samples on the recovery of uranium, a set of natural water samples were taken for the determination of uranium by the proposed method. Tables $1 \mathrm{~A}$ and $1 \mathrm{~B}$ shows the typical composition of natural water samples analyzed in this laboratory by different classical and instrumental techniques. The possibility cannot be ruled out that the adsorption of other co-existing ions present in water samples on microcrystalline naphthalene may interfere in the determination of uranium by LED/laser fluorimetry. Direct determination of uranium by laser/LED fluorimetry method in phosphate medium is not possible because of several quenching elements, like $\mathrm{Ca}, \mathrm{Fe}$, $\mathrm{Mn}, \mathrm{Cu}, \mathrm{Co}, \mathrm{Cr}, \mathrm{Ni}$, etc. if present above the tolerance level. Detailed studies on this quenching behavior of these elements have already been carried out in several works. ${ }^{27,28}$ The transition group elements generally present in a water sample at trace (ppb) levels (as shown in Table 1B), which are masked by $\mathrm{Na}_{2}$ EDTA, do not interfere in the determination of uranium by the proposed method because the tolerance levels of most of the quenching elements are at the ppm level. After preconcentration of the water sample by the proposed method, if $\mathrm{Ca}, \mathrm{Al}, \mathrm{Fe}$, etc. are present above the tolerance level $(\mathrm{Ca}$ and $\mathrm{Al}$ forms white precipitate in the presence of phosphate buffer, Fe quenches uranium fluorescence above the ratio of Fe to $\mathrm{U}: 100$ ), then uranium can be extracted by conventional liquid-liquid solvent extraction using aluminum nitrate as a salting out agent prior to LED fluorimetry determination. ${ }^{11}$ The tolerance limits of the common co-existing species in water samples by the proposed method are shown in Table 2.

\section{Validation and application of the method}

In order to validate the method developed and in order to attest the efficacy of the extractive system, the proposed method was thoroughly applied to a set of water samples. The proposed method has been applied for the determination of uranium in water samples containing varied matrix i.e., low TDS to high TDS collected from different field areas of eastern India for uranium exploration work. The results are shown in Table 3. In the direct determination of uranium in water samples, if present at sub ppb levels, the instrument (LED fluorimetry) yields 
Table 1A Concentration $\left(\mu \mathrm{g} \mathrm{mL}^{-1}\right)$ of major species in natural water samples (N.D. $=$ Not detected)

\begin{tabular}{crrrrrrrrrr}
\hline Sample No. & $\mathrm{Na}^{+}$ & $\mathrm{K}^{+}$ & $\mathrm{Ca}^{2+}$ & $\mathrm{Mg}^{2+}$ & $\mathrm{CO}_{3}^{2-}$ & $\mathrm{HCO}_{3}^{-}$ & $\mathrm{Cl}^{-}$ & $\mathrm{SO}_{4}^{2-}$ & $\mathrm{TDS}$ & $\mathrm{pH}^{2-}$ \\
\hline 1 & 13 & $<1$ & 10 & $<10$ & N.D. & 80 & 10 & $<10$ & 80 & 7.3 \\
2 & 30 & 2 & 42 & 25 & N.D. & 166 & 82 & 30 & 400 & 7.3 \\
3 & 45 & 1 & 56 & 15 & N.D. & 139 & 110 & 40 & 370 & 7.0 \\
4 & 21 & $<1$ & 12 & $<10$ & N.D. & 97 & 14 & $<10$ & 100 & 7.2 \\
5 & 15 & $<1$ & 14 & $<10$ & N.D. & 80 & 14 & $<10$ & 95 & 7.2 \\
6 & 54 & 2 & 10 & 35 & N.D. & 123 & 131 & 30 & 390 & 7.1 \\
7 & 35 & 1 & 28 & $<10$ & N.D. & 209 & 17 & $<10$ & 200 & 7.5 \\
8 & 15 & 1 & 24 & $<10$ & N.D. & 118 & 23 & $<10$ & 130 & 7.0 \\
9 & 38 & 1 & 54 & 42 & N.D. & 139 & 173 & 30 & 460 & 7.0 \\
10 & 13 & $<1$ & 16 & $<10$ & N.D. & 80 & 16 & $<10$ & 100 & 7.5 \\
\hline
\end{tabular}

Table 1B Concentration $\left(\mathrm{ng} \mathrm{mL}^{-1}\right)$ of trace elements in natural water samples

\begin{tabular}{|c|c|c|c|c|c|c|c|c|c|c|c|c|c|c|c|}
\hline Sample No. & $\mathrm{Fe}$ & $\mathrm{Al}$ & $\mathrm{Cu}$ & $\mathrm{Zn}$ & $\mathrm{Pb}$ & $\mathrm{Co}$ & $\mathrm{Bi}$ & $\mathrm{Cr}$ & $\mathrm{Ni}$ & B & Mo & $\mathrm{V}$ & As & $\mathrm{Se}$ & $\mathrm{U}$ \\
\hline 1 & 500 & 10 & $<5$ & 236 & 5 & $<5$ & $<5$ & $<5$ & $<5$ & $<5$ & 5 & 10 & $<5$ & 7 & $<1$ \\
\hline 2 & 300 & 14 & $<5$ & 17 & 14 & $<5$ & $<5$ & $<5$ & $<5$ & $<5$ & $<5$ & 59 & 22 & 6 & $<1$ \\
\hline 3 & 470 & 17 & $<5$ & 30 & 12 & $<5$ & $<5$ & $<5$ & $<5$ & $<5$ & 6 & 40 & 11 & 14 & $<1$ \\
\hline 4 & 590 & 10 & $<5$ & 21 & 9 & $<5$ & $<5$ & $<5$ & $<5$ & $<5$ & 13 & 10 & 20 & 10 & $<1$ \\
\hline 5 & 410 & 18 & $<5$ & 14 & 13 & $<5$ & $<5$ & $<5$ & $<5$ & $<5$ & 5 & 12 & 18 & $<5$ & $<1$ \\
\hline 6 & 110 & 30 & $<5$ & 65 & 16 & $<5$ & 8 & $<5$ & $<5$ & $<5$ & $<5$ & 37 & 29 & $<5$ & $<1$ \\
\hline 7 & 150 & 19 & $<5$ & 39 & 14 & $<5$ & 9 & $<5$ & $<5$ & $<5$ & 5 & 19 & 11 & 9 & $<1$ \\
\hline 8 & 140 & 26 & $<5$ & 23 & 13 & $<5$ & 5 & $<5$ & $<5$ & $<5$ & 5 & 15 & 15 & 10 & 1 \\
\hline 9 & 1050 & 30 & $<5$ & 20 & 16 & $<5$ & 7 & $<5$ & $<5$ & $<5$ & 7 & 41 & 20 & 21 & 5 \\
\hline 10 & 1320 & 23 & $<5$ & 52 & 14 & $<5$ & 14 & $<5$ & $<5$ & $<5$ & 8 & 15 & 14 & 14 & 10 \\
\hline
\end{tabular}

Table 2 Effect of diverse ions on the determination of $1 \mathrm{ppm}$ uranium by the proposed method

\begin{tabular}{|c|c|c|}
\hline S1. No. & Elements/species & Tolerance limit, ppm \\
\hline 1 & $\begin{array}{l}\mathrm{Na}, \mathrm{K}, \mathrm{Ca}, \mathrm{Mg}, \mathrm{Rb}, \mathrm{Sr}, \mathrm{Ba}, \mathrm{Cu}, \mathrm{V}, \\
\mathrm{Mo}, \mathrm{Zn}, \mathrm{Pb}, \mathrm{Al}, \mathrm{HCO}_{3}^{--}, \mathrm{Cl}^{-}, \mathrm{NO}_{3}^{-} \text {, } \\
\mathrm{SO}_{4^{2-}}, \mathrm{PO}_{4}{ }^{3-}\end{array}$ & 1000 \\
\hline 2 & $\mathrm{Fe}, \mathrm{Mn}, \mathrm{Cr}, \mathrm{Co}, \mathrm{Ni}$ & 100 \\
\hline
\end{tabular}

imprecise results i.e., with low precision (the fluorescence signal is marginally above that of process blank). However, when preconcentrated by solid phase extraction with microcrystalline naphthalene, uranium can be comfortably determined i.e., fluorescence signal much above that of process blank and yields high precision, which are shown in Table 3 . Therefore, preconcentration improves the precision and reliability of results.

In the absence of certified reference material for water samples, standard addition method has been applied to validate the percentage recovery values of this method, taking into consideration ground water samples that contain uranium below the determination limit of the method. The results are also shown in Tables 3 and 4 . The result indicates that the recoveries were reasonable for trace uranium analysis in the range 95 $100 \%$ with precision $1-12 \%$ RSD. The above standard addition method has been applied in order to nullify the matrix effect as well as the loss of analyte during several steps involved in the recommended procedure for recovery studies, which is defined as the addition of a known amount of analyte to a sample and then determining what percent of the amount added is detected. Similarly, the reliability of the results was also compared by analyzing the same water samples by pellet fluorimetry involving standard separation technique like co-precipitation using aluminum phosphate as a carrier. ${ }^{30}$ The results of the study are also shown in Table 4. The results in
Tables 3 and 4 indicate that the method developed is quite effective in the solid phase separation and preconcentration of uranium for their accurate determination by LED fluorimetry method.

\section{Conclusions}

The proposed solid phase extraction of uranium with microcrystalline naphthalene combined with LED fluorimetry determination is an effective alternative method for separation and preconcentration of trace and ultra-trace level uranium determination in water samples. At the alkaline $\mathrm{pH}$ of $10-12$, uranium is separated and preconcentrated from sample solutions by means of its complex formation with 2,3-dihydroxynaphthalene in the presence of CTAB, which adsorbed on microcrystalline naphthalene quantitatively. The method is highly effective for the determination of uranium in those water samples where uranium is present below the determination limit of the instrument. The higher preconcentration factor (100 fold) can also be achieved by concentrating a 1-L water sample into a $10-\mathrm{mL}$ volume by the proposed method. The detection limit and determination limit of the proposed method are 0.025 and $0.1 \mathrm{ppb}$ respectively in aqueous solution based on $3 \sigma$ and $10 \sigma$ of ten replicate measurements of blank sample, where $\sigma$ denotes standard deviation of the measurements. The developed method provides freedom from hazardous large amounts of the salting out agents like aluminum nitrate used in liquid-liquid solvent extraction of uranium in the conventional pellet fluorimetry method. The proposed method is simple, rapid and eco-friendly and can be applied to a variety of water samples, including seawater and effluents on a routine basis.

\section{Acknowledgements}

The authors express their sincere thanks and gratitude to Directors, AMD, Hyderabad and NIT, Jamshedpur for their kind 
Table 3 Results of uranium in water samples collected from the eastern part of India

\begin{tabular}{|c|c|c|c|c|c|c|c|}
\hline \multirow{2}{*}{$\begin{array}{c}\text { Sample } \\
\text { No. }\end{array}$} & \multicolumn{2}{|c|}{ U determined by present method ${ }^{\mathrm{a}}$} & \multirow{2}{*}{$\begin{array}{l}\text { U added/ } \\
\mathrm{ng} \mathrm{mL}^{-1}\end{array}$} & \multirow{2}{*}{$\begin{array}{l}\text { U found/ } \\
\text { ng mL } L^{-1}\end{array}$} & \multirow{2}{*}{$\begin{array}{c}\text { U recovery, } \\
\%\end{array}$} & \multicolumn{2}{|c|}{ U determined by direct method ${ }^{\mathrm{a}}$} \\
\hline & $\mathrm{U} / \mathrm{ng} \mathrm{mL}^{-1}$ & $\mathrm{RSD}, \%$ & & & & $\mathrm{U} / \mathrm{ng} \mathrm{mL}^{-1}$ & RSD, $\%$ \\
\hline 1 & 0.08 & 10 & 10 & 10.0 & 99 & $<1$ & 25 \\
\hline 2 & 0.1 & 8 & 10 & 10.1 & 100 & $<1$ & 17 \\
\hline 3 & 0.4 & 4 & 10 & 10.3 & 99 & $<1$ & 20 \\
\hline 4 & 0.2 & 5 & 10 & 10.2 & 100 & $<1$ & 20 \\
\hline 5 & 0.8 & 5 & 10 & 10.6 & 98 & $<1$ & 30 \\
\hline 6 & 0.8 & 6 & 10 & 10.5 & 97 & $<1$ & 25 \\
\hline 7 & 0.5 & 10 & 10 & 10.5 & 100 & $<1$ & 32 \\
\hline 8 & 1.1 & 5 & 10 & 11 & 99 & 1 & 12 \\
\hline 9 & 5.0 & 7 & 10 & 15.2 & 101 & 5 & 8 \\
\hline 10 & 10.2 & 6 & 10 & 20.0 & 99 & 10 & 5 \\
\hline
\end{tabular}

a. No. of three replicate determinations $(n=3)$.

Table 4 Results of traces of uranium in different water samples

\begin{tabular}{|c|c|c|c|c|c|c|}
\hline $\begin{array}{l}\text { Sample } \\
\text { No. }\end{array}$ & $\begin{array}{l}\mathrm{U} \text { found by proposed } \\
\operatorname{method}^{\mathrm{b}} / \mathrm{ng} \mathrm{mL}^{-1}\end{array}$ & $\begin{array}{c}\mathrm{RSD} \\
\%\end{array}$ & $\begin{array}{l}\mathrm{U} \text { found by standard } \\
\text { addition method } / \mathrm{ng} \mathrm{mL}^{-1}\end{array}$ & $\begin{array}{l}\mathrm{RSD} \\
\%\end{array}$ & $\begin{array}{l}\text { U found by pellet fluorimetry } \\
\text { method }^{\mathrm{a}, \mathrm{b}} / \mathrm{ng} \mathrm{mL}^{-1}\end{array}$ & $\begin{array}{c}\mathrm{RSD}, \\
\%\end{array}$ \\
\hline 1 & 1.8 & 6 & 1.9 & 8 & 1.9 & 10 \\
\hline 2 & 0.5 & 10 & 0.6 & 12 & 0.5 & 14 \\
\hline 3 & 1.2 & 5 & 1.0 & 10 & 1.2 & 8 \\
\hline 4 & 5.3 & 7 & 5.1 & 8 & 5.2 & 10 \\
\hline 5 & 10.2 & 6 & 9.9 & 8 & 10.5 & 8 \\
\hline
\end{tabular}

a. Separation and preconcentration of uranium by co-precipitation using aluminum phosphate as a carrier. b. No. of three replicate determinations $(n=3)$.

permission to do research work leading to a Ph.D. The authors are also thankful to Regional Director and Dy. Regional Director, AMD, Eastern Region, Jamshedpur for providing necessary facilities to carry out the work. Also, the authors are thankful to Head, Chemistry Group, AMD, Hyderabad and Dr. P. K. Tarafder, Ex-Incharge, Chemistry Laboratory, AMD, Jamshedpur for their constant encouragement, support and motivation to do the work.

\section{References}

1. H. C. Arora, "Chemical Analysis of Geological MaterialsTheory and Practice", 1st ed., 2003, A Publication of Chemistry Group, AMD/DAE, Govt. of India, Hyderabad, 80.

2. H. Onishi, "Photometric Determination of Trace Metals", 4th ed., 1989, Vol. Part IIB, A Wiley-Interscience Publication, John Wiley and Sons, New York, 608.

3. N. K. Agnihotri, V. K. Singh, and H. B. Singh, Talanta, 1993, 40, 1851.

4. I. Singh and R. Sahni, Talanta, 1994, 41, 2173.

5. L. Z. Han and L. Shaopu, Analyst, 1991, 116, 95.

6. K. W. Jackson and T. H. Mahmood, Anal. Chem., 1994, 66, 252R.

7. M. D. Amos and J. B. Wills, Spectrochim. Acta, 1996, 22, 1325.

8. A. M. Bond, V. S. Biskupsky, and D. A. Wark, Anal. Chem., 1974, 46, 1531.

9. M. Furukawa, M. Matsueda, and Y. Takagai, Anal. Sci., 2018, 34, 471.

10. A. Ramesh, J. Krishnamacharayulu, L. K. Ravindranath, and S. B. Rao, Analyst, 1992, 117, 1037.

11. S. K. Pradhan and B. Ambade, J. Radioanal. Nucl. Chem., 2019, 320, 459.

12. T. Nagano, H. Naganawa, H. Suzuki, M. Toshimitsu, H. Mitamura, N. Yanase, and B. Grambow, Anal. Sci., 2018, 34, 1099.
13. K. Venkatesh and B. Maity, Sep. Sci. Technol., 2004, 39, 1779.

14. S. Kumar, M. Krishnakumar, and A. A. Patwardhan, Explor. Res. Atomic Minerals, 2007, 17, 15.

15. P. N. Kumar, S. Kumar, V. Kumar, S. S. Nandakishore, and P. N. Bangroo, Explor. Res. Atomic Minerals, 2013, 23, 75.

16. Y. Shigetomi, T. Kojima, and H. Kamba, Anal. Chem. Acta, 1980, 116, 199.

17. T. Kojima and Y. Shigetomi, Talanta, 1989, 36, 603.

18. B. K. Puri, Atamjyot, K. Lal, and H. Bansal, Anal. Sci., 2002, $18,427$.

19. J. M. Gladis and T. P. Rao, Anal. Lett., 2002, 35, 501.

20. C. R. Preetha and T. P. Rao, Radiochim. Acta, 2003, 91, 247.

21. M. Behpour, S. M. Ghoreishi, Z. Nikkhah Qamsari, M. Samiei, and N. Soltani, Chin. J. Chem., 2010, 28, 1457.

22. P. K. Tarafder, P. Murugan, L. Kunkal, and D. P. S. Rathore, J. Radioanal. Nucl. Chem., 2002, 253, 135.

23. P. K. Tarafder, S. K. Pradhan, and R. K. Mondal, J. Radioanal. Nucl. Chem., 2016, 309, 1021.

24. P. K. Tarafder, S. K. Pradhan, R. K. Mondal, and J. K. Sircar, J. Indian Chem. Soc., 2013, 90, 1961.

25. R. Thakur, S. K. Pradhan, R. R. Jha, and P. K. Tarafder, Explor. Res. Atomic Minerals, 2013, 23, 117.

26. P. K. Tarafder and S. K. Pradhan, Explor. Res. Atomic Minerals, 2007, 17, 225.

27. J. C. Robbins, Can. Mining Metallurgy Bull., 1978, 71, 61.

28. M. Kumar and M. Krishnakumar, "A Manual on Fluorimetric Determination of Uranium in Geo-materials", 2017, A Publication of Chemistry Group, AMD/DAE, Govt. of India, Hyderabad, 70.

29. C. Cheng, Z. Wang, X. Liu, F. Tang, X. Pan, and C. Zheng, IEEE J. Quantum Electronics, 1986, 22, 998.

30. A. P. Smith and F. S. Grimaldi, US Geological Survey Bull., 1954, 1006, 125. 